\title{
Spatial and Seasonal Variation in Rain Use Efficiency in Semiarid Grasslands of Inner Mongolia
}

\author{
Jyoti Bhandari, ${ }^{1}$ Xuebiao Pan, ${ }^{1}$ and G. C. Dhruba Bijaya ${ }^{2,3}$ \\ ${ }^{1}$ College of Resources and Environmental Sciences, China Agricultural University, Beijing 100193, China \\ ${ }^{2}$ Institute of Geographic Sciences and Natural Resources Research, Chinese Academy of Sciences, Beijing 100101, China \\ ${ }^{3}$ University of Chinese Academy of Sciences, Beijing 100049, China
}

Correspondence should be addressed to Xuebiao Pan; panxb@cau.edu.cn

Received 4 December 2014; Revised 17 April 2015; Accepted 17 April 2015

Academic Editor: Julio Diaz

Copyright (C) 2015 Jyoti Bhandari et al. This is an open access article distributed under the Creative Commons Attribution License, which permits unrestricted use, distribution, and reproduction in any medium, provided the original work is properly cited.

\begin{abstract}
Rain use efficiency (RUE) is an important indicator for identifying the response of plant production to variation in precipitation patterns, especially in semiarid ecosystem grasslands of Inner Mongolia. We have investigated the response and spatial patterns of RUE to precipitation patterns based on five years $(2006,2007,2008,2012$, and 2013) of records from semiarid ecosystem sites across Inner Mongolia. Our results showed that $\mathrm{RUE}_{\mathrm{ADM}}$ was lowest in the wettest year (2012) and highest in the year following the driest year (2008). There was no significant correlation between $\mathrm{RUE}_{\mathrm{ADM}}$ and RUE $\mathrm{TDM}_{\mathrm{T}}$ in typical and desert steppe. RUE $\mathrm{TDM}_{\mathrm{TD}}$ was strongly correlated with both annual precipitation (AP) and growing season precipitation (GSP) compared to RUE $\mathrm{ADM}_{\mathrm{ADU}}$. RUE $\mathrm{ADM}$, therefore, cannot be used in place of $\mathrm{RUE}_{\mathrm{TDM}}$. $\mathrm{RUE}_{\mathrm{ADM}}$ increased with species richness. The relationship between RUE $\mathrm{ADM}_{\mathrm{And}}$ species richness was significantly correlated in meadow steppe, typical steppe, and desert steppe. Our findings can shed light on the spatial utilization pattern of seasonal rainfall in semiarid grassland ecosystems.
\end{abstract}

\section{Introduction}

In arid and semiarid ecosystems, precipitation is an important factor in controlling biodiversity and ecosystem functioning [1]. Rain use efficiency (RUE) is defined as the amount of biomass produced per unit of precipitation and is the key indicator for measuring the response of plant production to precipitation [2-4]. Previous studies conducted in semiarid ecosystems have shown that RUE decreases over time with increasing annual precipitation [5-8]. In addition to precipitation, factors such as vegetation composition, soil condition, and biogeochemical constraints may also affect rain use efficiency $[2,3,5,7]$. Higher diversity of plant species and functional groups may have greater RUE through increased productivity $[4,7,9-12]$. However, the interaction of RUE with seasonal precipitation patterns and spatial patterns of both above ground dry matter (ADM) and total dry matter (TDM) is not fully understood. Total dry matter is the sum of $\mathrm{ADM}$ and below ground dry matter (BDM).

In early studies [4, 12], the assessment of RUE was based on above ground net productivity, but not on total net productivity, which includes root systems [13]. Rain use efficiency based on above ground dry matter $\left(\mathrm{RUE}_{\mathrm{ADM}}\right)$ is sometimes used to evaluate rain use efficiency based on total plant dry matter (above ground + below ground) $\left(\mathrm{RUE}_{\mathrm{TDM}}\right)$. But it is debatable whether $\mathrm{RUE}_{\mathrm{ADM}}$ can significantly represent RUE $E_{\text {TDM }}(\mathrm{Gao}, 2013)$. The inclusion of root systems is equally important, since below ground biomass is directly related to soil conservation [13]. In particular, in drought prone sites, root systems are important for carbon sinks, which may not correspond to the carbon uptake of above ground plant organs [14]. Therefore our study aims to evaluate the correlation between $\mathrm{RUE}_{\mathrm{ADM}}$ and $\mathrm{RUE}_{\mathrm{TDM}}$. Estimates of RUE based on above ground dry matter, therefore, may be biased if used as a proxy to estimate total plant biomass productivity and carbon fixation efficiency relative to water uptake (Ying, 2013). This study was designed to (1) investigate the spatial patterns of rain use efficiency based on both above ground dry matter and total dry matter, (2) investigate RUE responses to seasonal precipitation, (3) evaluate the correlation between $\mathrm{RUE}_{\mathrm{ADM}}$ and species richness, based on a five year precipitation and above ground dry matter data 


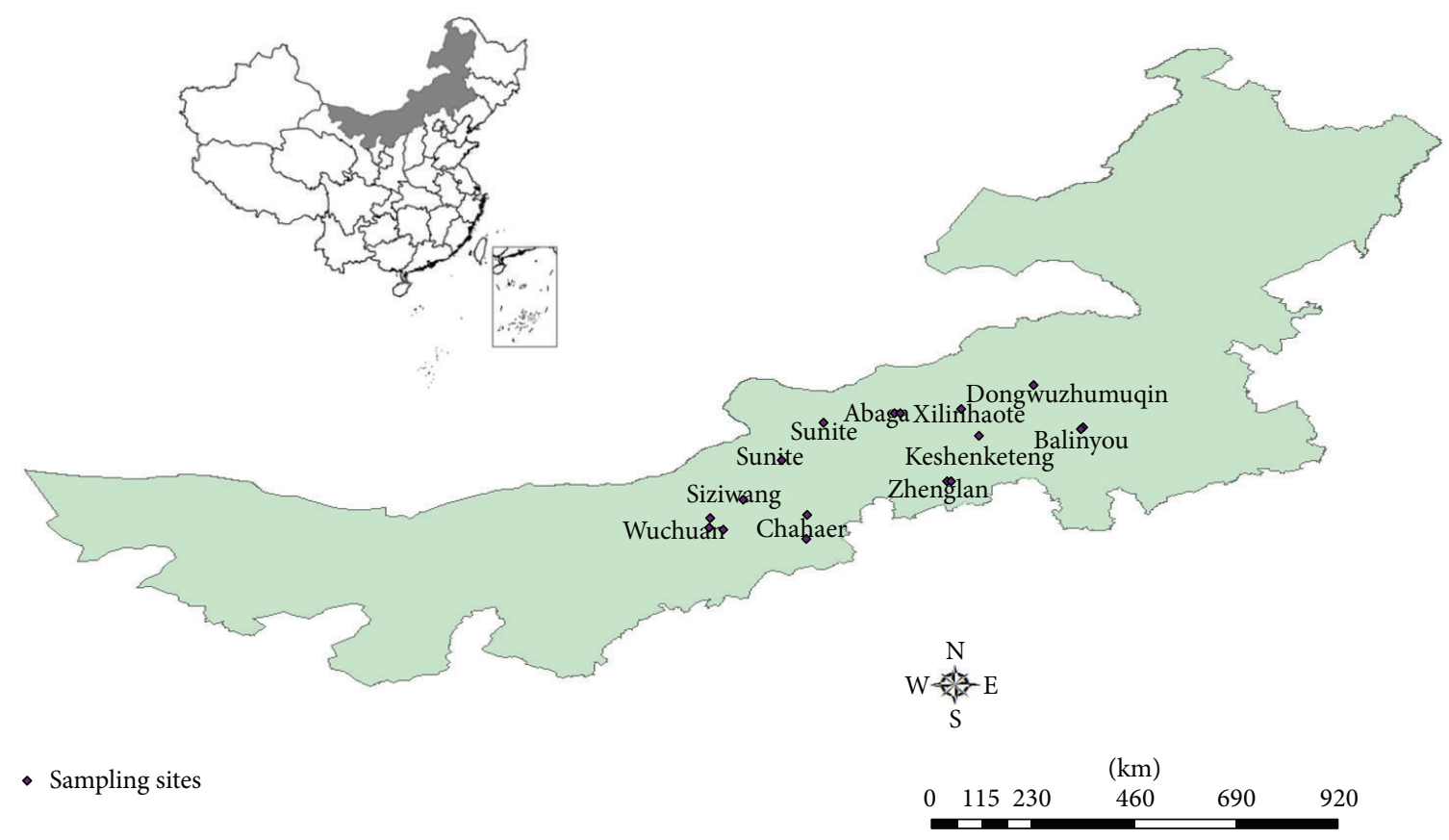

FIGURE 1: Study area and sampling sites in semiarid grassland, Inner Mongolia, China.

set, and (4) evaluate the correlation between $\mathrm{RUE}_{\mathrm{ADM}}$ and $\mathrm{RUE}_{\mathrm{TDM}}$ based on precipitation and total dry matter of one year data set across the Inner Mongolian region of China (Figure 1).

\section{Materials and Methods}

2.1. Study Area. The study was conducted in grasslands of Inner Mongolia, China (Figure 1), during the period from 2006 to 2013. A total of 34 semiarid sites were selected on an east-west transect, running from $\mathrm{N} 40^{\circ} 46^{\prime} 26^{\prime \prime}$ to $\mathrm{N} 49^{\circ} 16^{\prime} 31^{\prime \prime}$ latitude and $\mathrm{E} 108^{\circ} 59^{\prime} 38^{\prime \prime}$ to E122 $11^{\prime} 58^{\prime \prime}$ longitude (see the Appendix). The samples were collected from three vegetation types: meadow steppe, typical steppe, and desert steppe. A strong rainfall gradient partitions the region into a series of vegetation zones from the wetter east to the drier west. Meadow steppe, in the wettest part of the precipitation gradient, is the tallest and most productive of grassland types. Typical steppe consists of mid-height grass cover, whereas the driest of the three, desert steppe, is marked by patches of grass and shrubs separated by bare soil. Meadow steppe primarily covers the eastern part of the region, typical steppe stretches across the middle part of the region, and desert steppe covers the western region of Inner Mongolia (Figure 1). All the field sites are characterized by a continental, semiarid climate [15]. Mean annual precipitation of meadow, typical, and desert steppe ranges from 350 to $450 \mathrm{~mm}, 250$ to $350 \mathrm{~mm}$, and 200 to $250 \mathrm{~mm}$, respectively; likewise mean annual temperature of meadow, typical, and desert steppe ranges from -4 to $5^{\circ} \mathrm{C}$, -2 to $5^{\circ} \mathrm{C}$, and 4 to $6^{\circ} \mathrm{C}$, respectively (Fan, 2009). Amount and seasonal distribution of precipitation varied across the 5 years of the study period where 2012 was the wettest year $(411.5 \mathrm{~mm})$ and 2007 was the driest year $(227.6 \mathrm{~mm})$ (Figure 2).

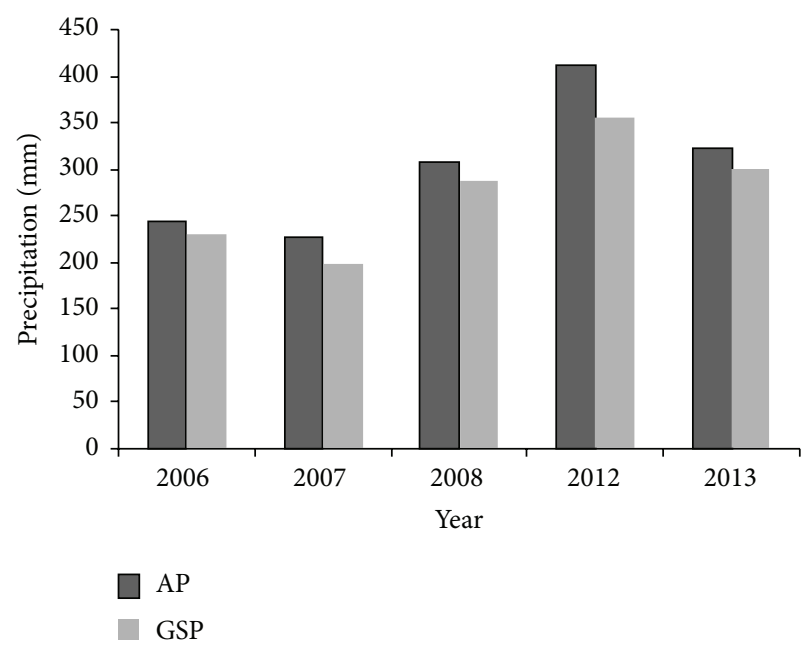

FIGURE 2: (AP) Annual precipitation ( $\mathrm{mm}$ ) growing season precipitation (mm) (GSP) of the study site in 2006, 2007, 2008, 2012, and 2013.

2.2. Data Collection and Sampling Methods. Above ground biomass sampling was done in August in 2006, 2007, 2008, 2012, and 2013. Vegetation was sampled at 6 sites in meadow steppe, 18 sites in typical steppe grassland, and 10 sites in desert steppe (see the Appendix). At each site, three $1 *$ $1 \mathrm{~m}$ quadrats were sampled at intervals of $30 \mathrm{~m}$ along a $100 \mathrm{~m}$ transect. This gave 18 sampled quadrants $(6 * 3)$ in meadow steppe, $54(18 * 3)$ sampled quadrants in typical steppe, and $30(10 * 3)$ sampled quadrants in desert steppe. For calculation and analysis based on above ground dry matter, the mean value for 5 years was taken. For some sites data were not measured for all 5 years (see the Appendix). 
TABLE 1: Differences in $\mathrm{RUE}_{\mathrm{ADM}}$ and $\mathrm{RUE}_{\mathrm{TDM}}\left(\mathrm{g} \mathrm{m}^{-2} \mathrm{~mm}^{-1}\right)$ between grassland type and precipitation years.

\begin{tabular}{lcccc}
\hline Year & Meadow & Typical & Desert & Year mean \\
\hline & & RUE $_{\text {ADM }}\left(\mathrm{g} \mathrm{m}^{-2} \mathrm{~mm}^{-1}\right)$ & & \\
2006 & $0.62 \pm 0.06$ & $0.51 \pm 0.02$ & $0.19 \pm 0.01$ & $0.44 \pm 0.07^{\mathrm{A}}$ \\
2007 & $0.52 \pm 0.04$ & $0.41 \pm 0.02$ & $0.55 \pm 0.03$ & $0.49 \pm 0.02^{\mathrm{A}}$ \\
2008 & $0.86 \pm 0.08$ & $0.46 \pm 0.03$ & $0.43 \pm 0.03$ & $0.58 \pm 0.07^{\mathrm{A}}$ \\
2012 & $0.53 \pm 0.04$ & $0.43 \pm 0.03$ & $0.38 \pm 0.02$ & $0.39 \pm 0.04^{\mathrm{A}}$ \\
2013 & $0.37 \pm 0.04$ & $0.48 \pm 0.02$ & $0.35 \pm 0.03^{\mathrm{Y}}$ & \\
Grassland type mean & $0.58 \pm 0.04^{\mathrm{X}}$ & $0.45 \pm 0.01^{\mathrm{XY}}$ & & $0.46 \pm 0.03$ \\
\hline & & RUE $_{\text {TDM }}\left(\mathrm{g} \mathrm{m}^{-2} \mathrm{~mm}^{-1}\right)$ & $1.64 \pm 0.10^{\mathrm{Z}}$ & \\
2013 & $3.80 \pm 0.30^{\mathrm{X}}$ & $2.76 \pm 0.14^{\mathrm{Y}}$ & & $2.73 \pm 0.13$ \\
\hline
\end{tabular}

Note. Significant differences in mean $\mathrm{RUE}_{\mathrm{ADM}}$ among years within grassland type are indicated by letters A and significant differences among grassland type by letters $\mathrm{X}-\mathrm{Z}$, respectively. Standard error $= \pm \mathrm{SE}$.

Plants were harvested in each sampling quadrat in order to measure above ground biomass. Plant materials were clipped at ground surface and litter was collected by hand. Below ground biomass sampling was done only in August of 2013. The soil profile was separated into soil depth intervals of 0 $10 \mathrm{~cm}, 10-20 \mathrm{~cm}, 20-30 \mathrm{~cm}$, and $30-40 \mathrm{~cm}$. Roots and other below ground biomass were separated from soil by washing with water through a $0.3 \mathrm{~mm}$-mesh sieve. The clipped above ground plant materials and below ground root materials were oven-dried at $80^{\circ} \mathrm{C}$ for 24 hours and then weighted $\left(\mathrm{g} \mathrm{m}^{-2}\right)$. Meteorological data from 2006 to 2013 were obtained from 15 instrumental weather stations within and adjacent to the study area from the China Meteorological Administration (http://www.cma.gov.cn/2011qxfw/).

2.3. Data Analysis. $\mathrm{RUE}_{\mathrm{ADM}}$ and $\mathrm{RUE}_{\mathrm{TDM}}$ for each sampling plots were calculated by using (1) and (2), respectively. Analysis of variance (ANOVA) was applied to test year (Y) and grassland types (S). To assess how each ecosystem responded, we further analyzed the relationship between both $\mathrm{RUE}_{\mathrm{ADM}}$ and $\mathrm{RUE}_{\mathrm{TDM}}$ with seasonal precipitation patterns such as annual precipitation and growing season precipitation by using correlation analysis. We conducted correlation analysis to investigate the relationship of $\mathrm{RUE}_{\mathrm{ADM}}$ to $\mathrm{RUE}_{\mathrm{TDM}}$ and the relationship of $\mathrm{RUE}_{\mathrm{ADM}}$ to species richness. All statistical analysis was performed using software package of SPSS 16.0 (SPSS Inc., Chicago, IL, USA):

$$
\begin{aligned}
\mathrm{RUE}_{\mathrm{ADM}} & =\frac{\mathrm{ADM}}{\mathrm{AP}}, \\
\mathrm{RUE}_{\mathrm{TDM}} & =\frac{\mathrm{TDM}}{\mathrm{AP}} .
\end{aligned}
$$

\section{Results and Discussion}

3.1. Grassland Type and Year Effects on RUE. In general, RUE tends to decrease with increasing aridity and potential evapotranspiration, both of which are closely related to ecosystem-level water balance [2]. We found that RUE $E_{A D M}$, based on above ground dry matter, varied from 0.19 to $0.86 \mathrm{~g} \mathrm{~m}^{-2} \mathrm{~mm}^{-1}$ and was highest in meadow steppe and lowest in desert steppe (Table 1). Similarly RUE based on total dry
TABLE 2: $F$ values and the probability of ANOVA analysis of RUE $\mathrm{ADM}$ and $\mathrm{RUE}_{\mathrm{TDM}}$.

\begin{tabular}{lcc}
\hline Source & Df & RUE $_{\text {ADM }}(F$ value $)$ \\
\hline Grassland type $(G T)$ & 2 & $8.62^{* *}$ \\
Year & 4 & $2.89^{*}$ \\
Year $^{*}(\mathrm{GT})$ & 8 & $3.87^{* *}$ \\
\hline Source & Df & $\mathrm{RUE}_{\mathrm{TDM}},(F$ value $)$ \\
\hline GT & 2 & $10.57^{* *}$ \\
\hline
\end{tabular}

Note. $\mathrm{RUE}_{\mathrm{ADM}}=$ rain use efficiency based on above ground dry matter, $\mathrm{RUE}_{\mathrm{TDM}}=$ rain use efficiency based on total dry matter, and Df = degrees of freedom. ${ }^{* *} P<0.001$ and ${ }^{*} P<0.05$.

matter $\left(\mathrm{RUE}_{\mathrm{TDM}}\right)$ varied between 1.64 and $3.80 \mathrm{~g} \mathrm{~m}^{-2} \mathrm{~mm}^{-1}$ and was highest in meadow steppe and lowest in desert steppe. Our result was consistent with Bai et al. [4], who show that RUE tends to increase with MAP from desert in the west to the meadow steppe in the east. In support of our results, some previous studies also show that drier sites tend to have lower and less variable RUE because of low plant density, low production potential, high evaporation potential, and high tolerance to water stress $[7,16,17]$.

For rain use efficiency based on above ground dry matter $\left(\mathrm{RUE}_{\mathrm{ADM}}\right)$, there was a significant interaction between precipitation year and grassland type (Table 2). This was true for species richness, with a significant interaction between precipitation year and grassland type (Table 3 ). The general trend is that with a decrease in precipitation, there is a decrease in above ground dry matter, leading to higher RUE in dry year. $\mathrm{RUE}_{\mathrm{ADM}}$ was lowest in 2012, which is the wettest year of our study period. However, previous studies also showed that a dry year following a wet year usually has high RUE for a given site (Le Houe'rou et al. 1984 [18]). Gao et al. [19] found that RUE based on above ground biomass was highest in the dry year 2005. This result was not consistent with our findings, as $\mathrm{RUE}_{\mathrm{ADM}}$ was not highest in dry year 2007, but in 2008, the year following the dry year. Bai et al. [4] reported that above ground productivity increases during wet years more than it declines in dry years. This was because soil water storage of the previous year's precipitation was available in the subsequent dry year. 
TABLE 3: $F$ values and the probability of ANOVA results on species richness.

\begin{tabular}{lcc}
\hline Source & Df & RUE $_{\text {ADM }}(F$ value $)$ \\
\hline GT & 2 & $28.26^{* *}$ \\
Year & 4 & $19.19^{*}$ \\
Year $^{*}(G T)$ & 8 & $4.18^{* *}$
\end{tabular}

Note. RUE $_{\mathrm{ADM}}=$ rain use efficiency based on above ground dry matter, $\mathrm{GT}=$ grassland type, and $\mathrm{Df}=$ degrees of freedom. ${ }^{*} P<0.001$ and ${ }^{*} P<$ 0.05 .

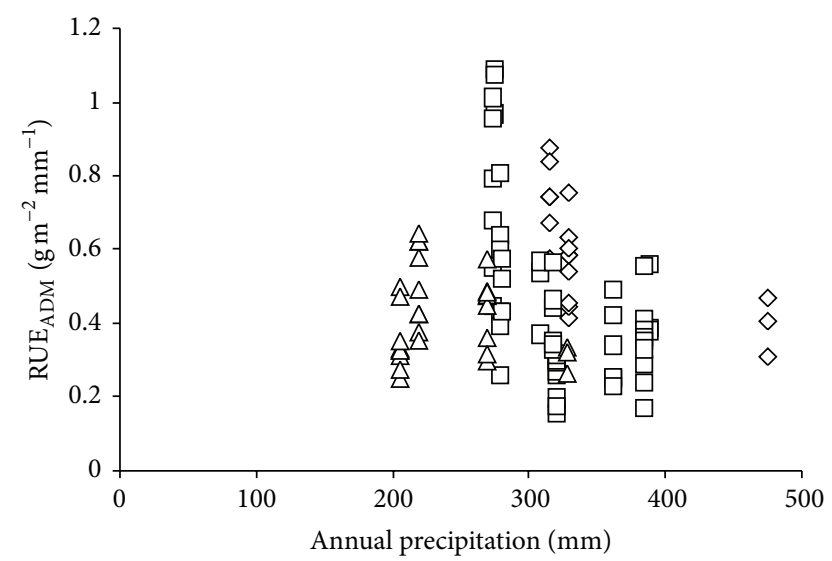

$$
\begin{aligned}
& \diamond \text { Meadow } \\
& \square \text { Typical } \\
& \Delta \text { Desert }
\end{aligned}
$$

FIgURE 3: Relationship of $\operatorname{RUE}_{\mathrm{ADM}}\left(\mathrm{g} \mathrm{m}^{-2} \mathrm{~mm}^{-1}\right)$ with annual precipitation $(\mathrm{mm})$ in meadow steppe, typical steppe, and desert steppe across the grasslands of Inner Mongolia. $\mathrm{RUE}_{\mathrm{ADM}}=$ rain use efficiency based on above ground dry matter.

3.2. Relationship between Seasonal Precipitations with $R U E_{A D M}$. Our analysis shows that $\mathrm{RUE}_{\mathrm{ADM}}$ decreased with both increased annual precipitation and growing season precipitation. $\mathrm{RUE}_{\mathrm{ADM}}$ was significantly correlated with annual precipitation in meadow steppe $(R=-0.628$, $P<0.05$, Figure 3$)$ and typical steppe $(R=-0.540, P<0.05$, Figure 3). Likewise $\mathrm{RUE}_{\mathrm{ADM}}$ was significantly correlated with growing season precipitation in meadow steppe $(R$ $=-0.778, P<0.001$, Figure 4$)$ and typical steppe $(R=$ $-0.652, P<0.001$, Figure 4). However, in desert steppe RUE $_{\text {ADM }}$ does not significantly correlate with either annual precipitation or growing season precipitation. This may be due to the constraints on growth in vegetation due to less rainfall in desert steppe compared to meadow and typical steppe. Above ground dry matter was more abundant at the wetter site. Mean relative biomass of above ground dry matter was $47.82 \%$ for meadow steppe, $30.33 \%$ for typical steppe, and $21.83 \%$ for desert steppe.

3.3. Effects of Seasonal Precipitation on $R U E_{T D M}$. RUE $E_{T D M}$ decreased significantly with increasing annual precipitation and growing season precipitation. Our result showed that RUE $_{\mathrm{TDM}}$ was strongly correlated with annual precipitation in meadow steppe $(R=-0.833, P<0.001$, Figure 5$)$, typical

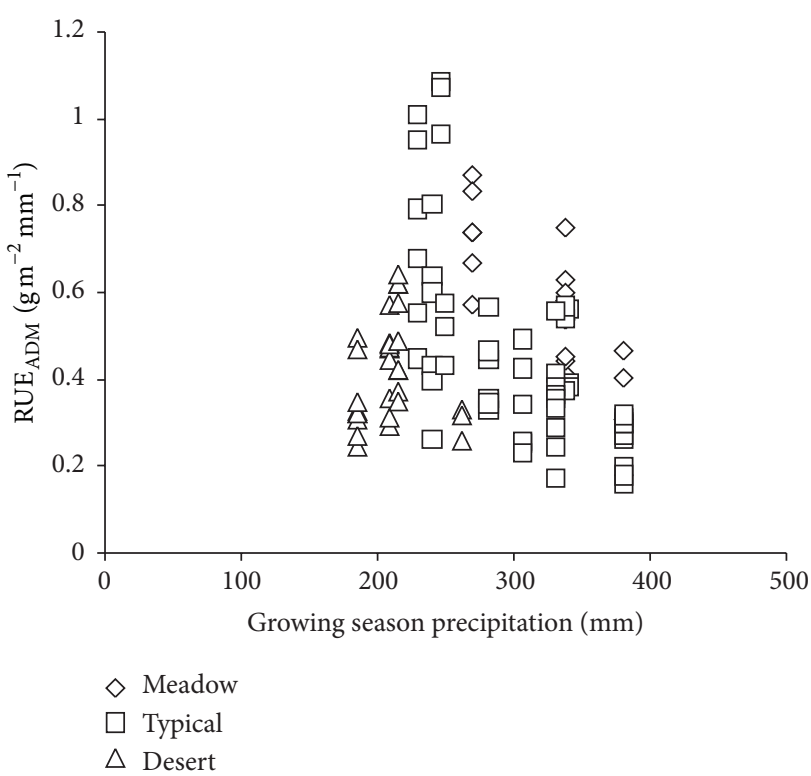

Figure 4: Relationship of $\mathrm{RUE}_{\mathrm{ADM}}\left(\mathrm{g} \mathrm{m}^{-2} \mathrm{~mm}^{-1}\right)$ with growing season precipitation $(\mathrm{mm})$ in meadow steppe, typical steppe, and desert steppe across the grassland of Inner Mongolia. $\mathrm{RUE}_{\mathrm{ADM}}=$ rain use efficiency based on above ground dry matter.

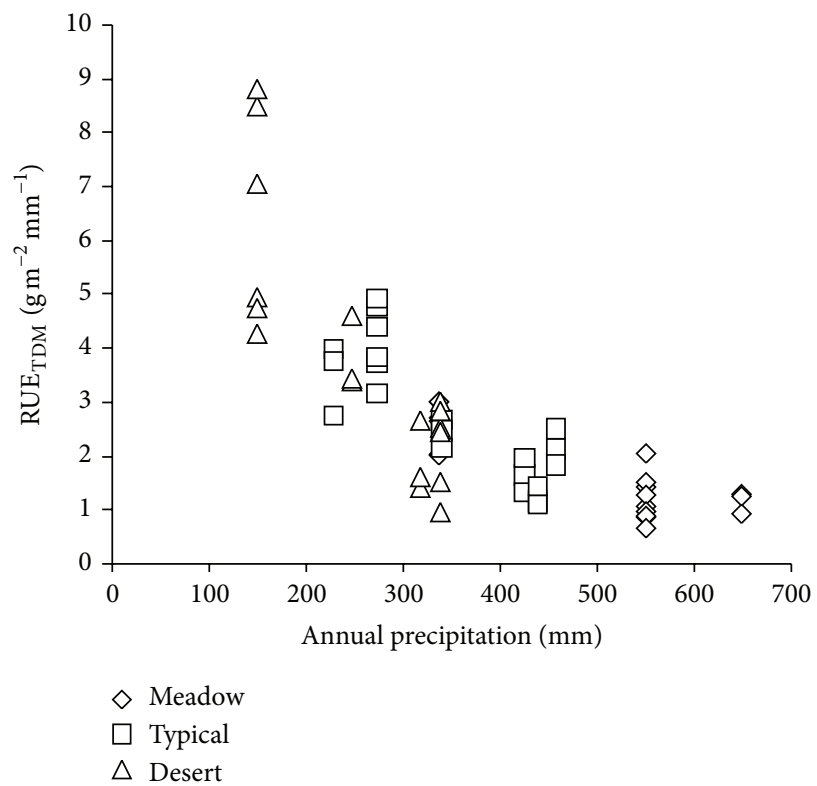

FIGURE 5: Relationship of RUE $\mathrm{TDM}_{\mathrm{T}}\left(\mathrm{g} \mathrm{m}^{-2} \mathrm{~mm}^{-1}\right)$ with annual precipitation in meadow steppe, typical steppe, and desert steppe across the grassland of Inner Mongolia. $\mathrm{RUE}_{\mathrm{TDM}}=$ rain use efficiency based on total dry matter.

steppe ( $R=-0.824, P<0.001$, Figure 5$)$, and desert steppe $(R=-0.842, P<0.001$, Figure 5). Likewise, the relationship between $R E_{\text {TDM }}$ with growing season precipitation (GSP) is strongly correlated in all three grassland type meadow steppe $(R=-0.833, P<0.001$, Figure 6$)$, typical steppe $(R=-0.835$, $P<0.001$, Figure 6$)$, and desert steppe $(R=-0840, P<$ $0.001)$. 


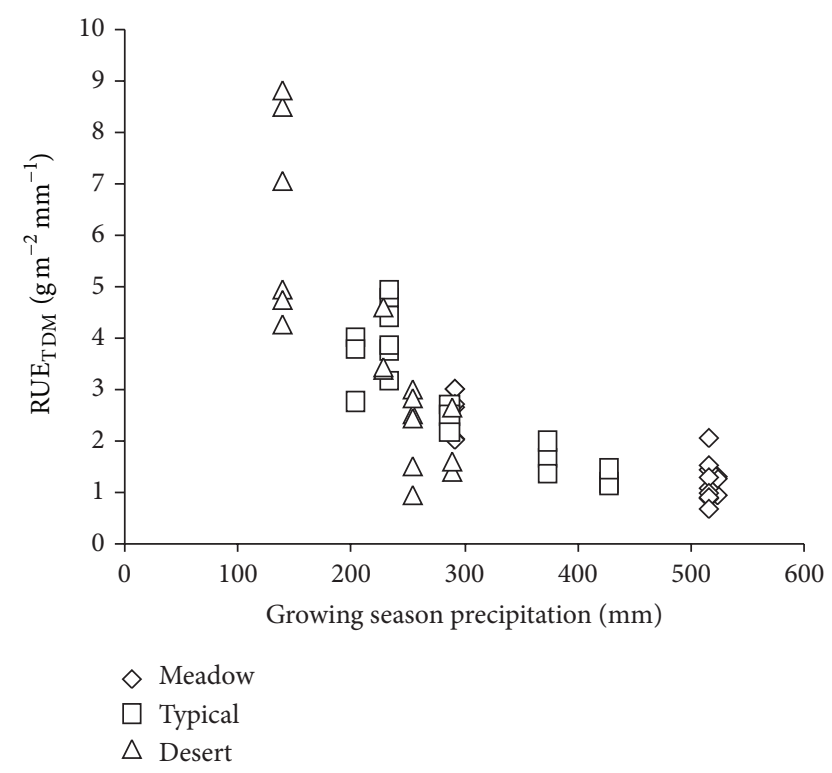

FIGURE 6: Relationship of $\mathrm{RUE}_{\mathrm{TDM}}\left(\mathrm{g} \mathrm{m}^{-2} \mathrm{~mm}^{-1}\right)$ with growing season precipitation in meadow steppe, typical steppe, and desert steppe across the grassland of Inner Mongolia. $\mathrm{RUE}_{\mathrm{TDM}}=$ rain use efficiency based on total dry matter.

Although there was a significant correlation between $\mathrm{RUE}_{\mathrm{ADM}}$ and RUE $\mathrm{TDM}_{\mathrm{T}}$ at sites of meadow steppe $(R=0.725$, $P<0.05$, Figure 7), the correlation between $\mathrm{RUE}_{\mathrm{ADM}}$ and RUE $_{\text {TDM }}$ in typical and desert steppe was not significant. Our results show that rain use efficiency based on total dry matter was strongly correlated to the precipitation gradient compared to rain use efficiency based on above ground dry matter. Thus, our results suggest that $\mathrm{RUE}_{\mathrm{ADM}}$ does not reflect $\mathrm{RUE}_{\mathrm{TDM}}$ in semiarid grassland of Inner Mongolia. In contrast to our results, Gao et al. [19] observed that RUE based on above ground productivity can be used as a proxy for RUE based on total productivity in ungrazed and winter grazing sites. Although our results showed that $R_{A D E}$ does not reflect $R_{A D E}$, the limitation of our study is that RUE $\mathrm{TDM}_{\mathrm{T}}$ was measured only for one year. The relative percentage of below ground dry matter in our study was $84.69 \%$, and there was inconsistent partitioning between shoot and root systems. Rain used efficiency, based on total dry matter, therefore, is not significantly correlated with rain used efficiency based on above ground dry matter.

3.4. Species Richness and $R U E_{A D M}$. RUE $\mathrm{E}_{\mathrm{ADM}}$ also increased with species richness indices. The relationship between RUE $_{\text {ADM }}$ with species richness was significantly correlated in meadow steppe $(R=0.713, P<0.05$, Figure 8$)$, typical steppe $(R=0.458, P<0.05$, Figure 8$)$, and desert steppe $(R=0.398, P<0.05)$. According to Bai et al. [4] plant species richness in Inner Mongolia increased linearly with annual precipitation (AP) and above ground biomass. Our results show that with an increase in species richness, there was increase in $\mathrm{RUE}_{\mathrm{ADM}}$. Yang et al. [12] observed that RUE in both Alpine steppe and meadow steppe increased with species richness, which is consistent with our results. This was mainly because more species may mean more biomass [20],

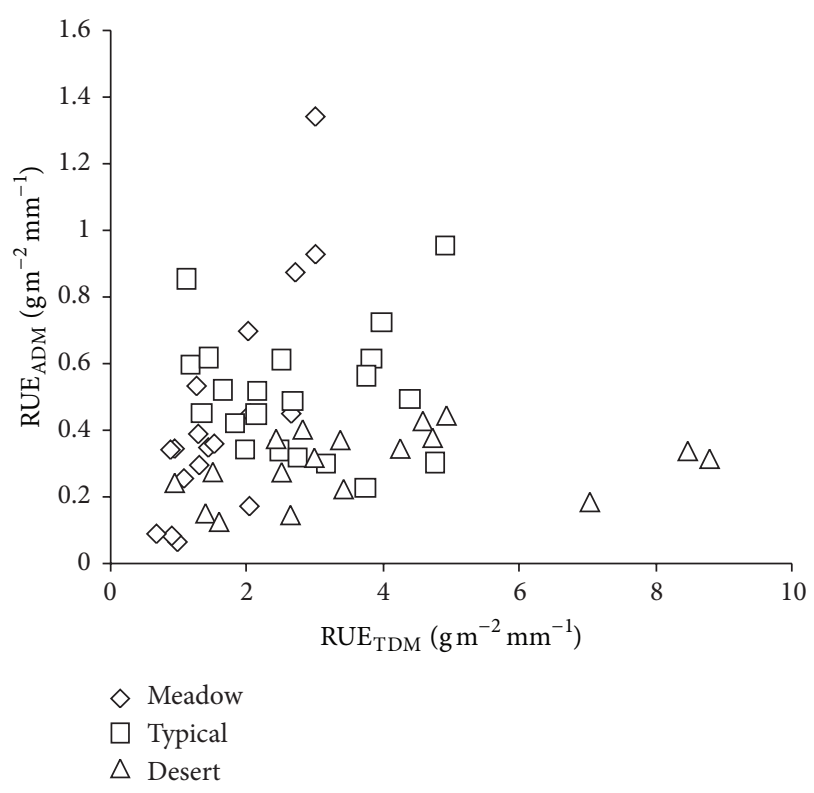

FIgURE 7: Relationship between $\operatorname{RUE}_{\mathrm{ADM}}\left(\mathrm{g} \mathrm{m}^{-2} \mathrm{~mm}^{-1}\right)$ and $\operatorname{RUE}_{\mathrm{TDM}}\left(\mathrm{g} \mathrm{m}^{-2} \mathrm{~mm}^{-1}\right)$ in meadow steppe, typical steppe, and desert steppe across the grassland of Inner Mongolia. $\mathrm{RUE}_{\mathrm{ADM}}=$ rain use efficiency based on above ground dry matter, $\mathrm{RUE}_{\mathrm{TDM}}=$ rain use efficiency based on total dry matter.

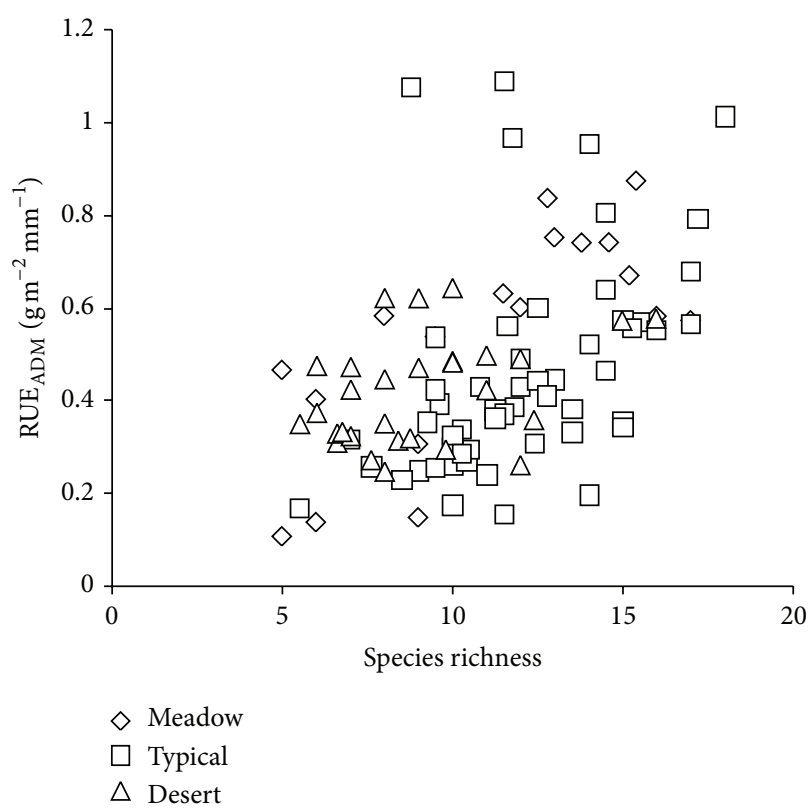

FIGURE 8: Relationship of $\mathrm{RUE}_{\mathrm{ADM}}\left(\mathrm{g} \mathrm{m}^{-2} \mathrm{~mm}^{-1}\right)$ with species richness in meadow steppe, typical steppe, and desert steppe across the grassland of Inner Mongolia. $\mathrm{RUE}_{\mathrm{ADM}}=$ rain use efficiency based on above ground dry matter.

resulting from complete use of available water due to niche partitioning. Another reason may be that high species rich ecosystems may contain functional groups which respond to higher precipitation. For example, ecosystems dominated by mesophytic grasses respond more strongly to precipitation than systems dominated by xerophytic grasses $[7,12]$. 
TABLE 4: Geographical extent, climatic ranges, and above ground dry matter data measured year of sites sampled in Inner Mongolia.

\begin{tabular}{|c|c|c|c|c|c|c|}
\hline Site name & Grassland type & Longitude & Latitude & MAP (mm) & $\operatorname{MAT}\left({ }^{\circ} \mathrm{C}\right)$ & ADM measured year \\
\hline Alukeerqinqi & Meadow steppe & $\mathrm{E} 119^{\circ} 58^{\prime} 36^{\prime \prime}$ & $\mathrm{N} 43^{\circ} 50^{\prime} 18^{\prime \prime}$ & 462.4 & -2.29 & 2013 \\
\hline Zaluteqi & Meadow steppe & $\mathrm{E} 121^{\circ} 1^{\prime} 24^{\prime \prime}$ & $\mathrm{N} 44^{\circ} 39^{\prime} 4.3^{\prime \prime}$ & 373.6 & 7.07 & 2013,2012 \\
\hline Zaluteqi & Meadow steppe & $\mathrm{E} 119^{\circ} 46^{\prime} 28^{\prime \prime}$ & $\mathrm{N} 45^{\circ} 23^{\prime} 14^{\prime \prime}$ & 373.6 & 7.07 & 2013 \\
\hline Keerqin youyi qianqi & Meadow steppe & $\mathrm{E} 122^{\circ} 11^{\prime} 58^{\prime \prime}$ & $\mathrm{N} 46^{\circ} 11^{\prime} 26^{\prime \prime}$ & 373.6 & 7.07 & 2013 \\
\hline Xiwuzhumuqin & Meadow steppe & $\mathrm{E} 117^{\circ} 49^{\prime} 35^{\prime \prime}$ & $\mathrm{N} 44^{\circ} 39^{\prime} 15^{\prime \prime}$ & 339.8 & 4.84 & 2013, 2012, 2008, 2007, 2006 \\
\hline Xiwuzhumuqin qi & Meadow steppe & $\mathrm{E} 117^{\circ} 41^{\prime} 58^{\prime \prime}$ & $\mathrm{N} 44^{\circ} 36^{\prime} 16^{\prime \prime}$ & 339.8 & 4.84 & 2013, 2012, 2008, 2007, 2006 \\
\hline Balinyouqi & Typical steppe & $\mathrm{E} 118^{\circ} 47^{\prime} 27^{\prime \prime}$ & $\mathrm{N} 43^{\circ} 36^{\prime} 36^{\prime \prime}$ & 385.1 & 3.23 & 2013, 2012, 2008, 2007, 2006 \\
\hline Dongwuzhumuqinqi & Typical steppe & $\mathrm{E} 118^{\circ} 48^{\prime} 20^{\prime \prime}$ & $\mathrm{N} 45^{\circ} 38^{\prime} 45^{\prime \prime}$ & 259.2 & 6.52 & 2013, 2012, 2008, 2007 \\
\hline Chenbaerhuqi & Typical steppe & $\mathrm{E} 119^{\circ} 4^{\prime} 39^{\prime \prime}$ & $\mathrm{N} 49^{\circ} 16^{\prime} 31^{\prime \prime}$ & 245.3 & 1.8 & 2013 \\
\hline Xilinhaote & Typical steppe & $\mathrm{E} 116^{\circ} 19^{\prime} 25^{\prime \prime}$ & $\mathrm{N} 44^{\circ} 07^{\prime} 5^{\prime \prime}$ & 274.7 & 1.32 & 2013, 2012, 2006 \\
\hline Xilinhaote & Typical steppe & $\mathrm{E} 115^{\circ} 56^{\prime} 50^{\prime \prime}$ & $\mathrm{N} 43^{\circ} 56^{\prime} 28^{\prime \prime}$ & 274.7 & 1.32 & $2013,2012,2008,2007$ \\
\hline Abagaqi & Typical steppe & $\mathrm{E} 114^{\circ} 59^{\prime} 23^{\prime \prime}$ & $\mathrm{N} 44^{\circ} 0^{\prime} 28^{\prime \prime}$ & 244.5 & 2.37 & $2013,2008,2007,2006$ \\
\hline Abagaqi & Typical steppe & $\mathrm{E} 115^{\circ} 03^{\prime} 48^{\prime \prime}$ & $\mathrm{N} 44^{\circ} 00^{\prime} 6.0^{\prime \prime}$ & 244.5 & 2.37 & $2012,2008,2007$ \\
\hline Ewenkezu zizhiqi & Typical steppe & $\mathrm{E} 119^{\circ} 42^{\prime} 39^{\prime \prime}$ & $\mathrm{N} 49^{\circ} 4^{\prime} 13^{\prime \prime}$ & 270.5 & 7.87 & 2013 \\
\hline Wuchuanxian & Typical steppe & $\mathrm{E} 111^{\circ} 46^{\prime} 33^{\prime \prime}$ & $\mathrm{N} 41^{\circ} 41^{\prime} 12^{\prime \prime}$ & 352.4 & 5.82 & 2013,2006 \\
\hline Wuchuanxian & Typical steppe & $\mathrm{E} 111^{\circ} 12^{\prime} 09^{\prime \prime}$ & $\mathrm{N} 41^{\circ} 07^{\prime} 53^{\prime \prime}$ & 352.4 & 5.82 & 2012 \\
\hline Wuchuanxian & Typical steppe & $\mathrm{E}_{111^{\circ}} 29^{\prime} 2^{\prime \prime}$ & $\mathrm{N} 41^{\circ} 1^{\prime} 29^{\prime \prime}$ & 352.4 & 5.82 & 2012,2008 \\
\hline Chahaeryouyiqianqi & Typical steppe & $\mathrm{E} 113^{\circ} 11^{\prime} 23^{\prime \prime}$ & $\mathrm{N} 40^{\circ} 46^{\prime} 26^{\prime \prime}$ & 363.9 & 4.65 & $2008,2007,2006$ \\
\hline Chahaeryouyiqianqi & Typical steppe & $\mathrm{E}_{113^{\circ}} 10^{\prime} 51^{\prime \prime}$ & $\mathrm{N} 41^{\circ} 24^{\prime} 36^{\prime \prime}$ & 363.9 & 4.65 & 2012, 2008, 2007 \\
\hline Keshenketengqi & Typical steppe & $\mathrm{E} 116^{\circ} 41^{\prime} 29^{\prime \prime}$ & $\mathrm{N} 43^{\circ} 26^{\prime} 54^{\prime \prime}$ & 380 & 5.8 & $2008,2007,2006$ \\
\hline Keshenketengqi & Typical steppe & $\mathrm{E} 117^{\circ} 48^{\prime} 57^{\prime \prime}$ & $\mathrm{N} 43^{\circ} 28^{\prime} 48^{\prime \prime}$ & 380 & 5.8 & 2006 \\
\hline Zhenglanqi & Typical steppe & $\mathrm{E} 116^{\circ} 02^{\prime} 54^{\prime \prime}$ & $\mathrm{N} 42^{\circ} 16^{\prime} 1^{\prime \prime}$ & 381.9 & 3.48 & $2012,2008,2007,2006$ \\
\hline Zhenglanqi & Typical steppe & $\mathrm{E} 116^{\circ} 05^{\prime} 41^{\prime \prime}$ & $\mathrm{N} 42^{\circ} 15^{\prime} 42^{\prime \prime}$ & 381.9 & 3.48 & $2013,2008,2007,2006$ \\
\hline Zhenglanqi & Typical steppe & $\mathrm{E} 116^{\circ} 05^{\prime} 33^{\prime \prime}$ & $\mathrm{N} 42^{\circ} 15^{\prime} 33^{\prime \prime}$ & 381.9 & 3.48 & 2008,2007 \\
\hline Daerhanmamingan qi & Desert steppe & $\mathrm{E} 111^{\circ} 12^{\prime} 13^{\prime \prime}$ & $\mathrm{N} 41^{\circ} 20^{\prime} 50^{\prime \prime}$ & 258.6 & 5.19 & $2013,2012,2008,2007,2006$ \\
\hline Daerhanmamingan qi & Desert steppe & $\mathrm{E} 110^{\circ} 29^{\prime} 51^{\prime \prime}$ & $\mathrm{N} 41^{\circ} 37^{\prime} 37^{\prime \prime}$ & 258.6 & 5.19 & 2012 \\
\hline Daerhanmamingan qi & Desert steppe & $\mathrm{E} 110^{\circ} 23^{\prime} 32^{\prime \prime}$ & $\mathrm{N} 41^{\circ} 34^{\prime} 56^{\prime \prime}$ & 258.6 & 5.19 & 2012 \\
\hline Wulatezhongqi & Desert steppe & $\mathrm{E} 109^{\circ} 32^{\prime} 34^{\prime \prime}$ & $\mathrm{N} 41^{\circ} 25^{\prime} 05^{\prime \prime}$ & 204 & 3.71 & 2013 \\
\hline Wulatezhongqi & Desert steppe & $\mathrm{E} 108^{\circ} 59^{\prime} 38^{\prime \prime}$ & $\mathrm{N} 41^{\circ} 28^{\prime} 59^{\prime \prime}$ & 204 & 3.71 & 2013 \\
\hline Wulatezhongqi & Desert steppe & $\mathrm{E} 108^{\circ} 31^{\prime} 14^{\prime \prime}$ & $\mathrm{N} 41^{\circ} 31^{\prime} 19^{\prime \prime}$ & 204 & 3.71 & 2012 \\
\hline Sunitezouqi & Desert steppe & $\mathrm{E} 113^{\circ} 35^{\prime} 17^{\prime \prime}$ & $\mathrm{N} 43^{\circ} 46^{\prime} 30^{\prime \prime}$ & 185.1 & 4.25 & $2013,2012,2008,2006$ \\
\hline Sunitezouqi & Desert steppe & $\mathrm{E} 112^{\circ} 40^{\prime} 7^{\prime \prime}$ & $\mathrm{N} 42^{\circ} 48^{\prime} 13^{\prime \prime}$ & 185.1 & 4.51 & 2013, 2012, 2008, 2007, 2006 \\
\hline Sunitezouqi & Desert steppe & $\mathrm{E} 113^{\circ} 31^{\prime} 16^{\prime \prime}$ & $\mathrm{N} 43^{\circ} 46^{\prime} 33^{\prime \prime}$ & 185.1 & 4.51 & $2012,2008,2007$ \\
\hline Siziwangqi & Desert steppe & E111 $46^{\prime} 33^{\prime \prime}$ & $\mathrm{N} 41^{\circ} 41^{\prime} 12^{\prime \prime}$ & 169.9 & 4.77 & $2013,2012,2008,2006$ \\
\hline
\end{tabular}

Note. $\mathrm{MAP}=$ mean annual precipitation, $\mathrm{MAT}=$ mean annual air temperature, and ADM = above ground dry matter. MAP and MAT values were averaged over 2006, 2007, 2008, 2012, and 2013.

\section{Conclusions}

This study provides a broad analysis of RUE based on both above ground dry matter and total dry matter in 3 semiarid grassland types in the Inner Mongolia of China. Our results show that rain use efficiency based on both above ground dry matter and total dry matter was significantly higher in meadow steppe and lower in desert steppe. $\mathrm{RUE}_{\mathrm{ADM}}$ was found to be lowest in the wettest year (2012) and highest in the year following the driest year (2008). Rain use efficiency based on above ground dry matter was significantly correlated with precipitation in meadow and typical steppe. $\mathrm{RUE}_{\mathrm{TDM}}$ was strongly correlated with both mean annual precipitation and growing season precipitation in comparison to $\mathrm{RUE}_{\mathrm{ADM}}$. Therefore, rain use efficiency based on above ground dry matter cannot be used as proxy for rain use efficiency based on total dry matter. The relationship between $\mathrm{RUE}_{\mathrm{ADM}}$ with species richness was significantly positive in meadow steppe, typical steppe, and desert steppe, as $\mathrm{RUE}_{\mathrm{ADM}}$ increased with species richness. The differences in rain use efficiency in meadow steppe to desert steppe are due to differentiation in vegetation type. Future research should include a comprehensive analysis of biogeochemical components in relation with rain use efficiency in the semiarid grasslands of Inner Mongolia.

\section{Appendix}

See Table 4 . 


\section{Conflict of Interests}

The authors declare that there is no conflict of interests regarding the publication of this paper.

\section{Acknowledgments}

Research was funded by National Basic Research Program of China "973" (2012CB956204) and National Nature Science Fund (NSFC) Project (41271053, 41475104, 41075084). The authors wish to thank Melissa Savage of University of California, Los Angeles, for her useful comments on the paper. Special thanks are due to Lizhen Zhang, Xu Lin, Long Buju, Pei Wei, Changxiu Shao, Qiu Yue Li,Wei Xiao Yu, Zhang Xu Ting, Wang Ziwen and Bai HuiQing who have contributed to data collection and management of field survey over the years.

\section{References}

[1] J. F. Reynolds and D. M. S. Smith, "Do humans cause deserts?" in Global Desertification: Do Humans Cause Deserts? J. F. Reynolds and D. M. S. Smith, Eds., pp. 1-21, Dahlem University Press, Berlin, Germany, 2002.

[2] H. N. Le Houerou, "Rain use efficiency: a unifying concept in arid-land ecology," Journal of Arid Environments, vol. 7, no. 3, pp. 213-247, 1984.

[3] T. E. Huxman, M. D. Smith, P. A. Fay et al., "Convergence across biomes to a common rain-use efficiency," Nature, vol. 429, no. 6992, pp. 651-654, 2004.

[4] Y. F. Bai, J. G. Wu, Q. Xing et al., "Primary production and rain use efficiency across a precipitation gradient on the Mongolia plateau," Ecology, vol. 89, no. 8, pp. 2140-2153, 2008.

[5] W. K. Lauenroth and O. E. Sala, "Long-term forage production of North American shortgrass steppe," Ecological Applications, vol. 2, no. 4, pp. 397-403, 1992.

[6] J. M. Briggs and A. K. Knapp, "Interannual variability in primary production in tallgrass prairie: climate, soil moisture, topographic position, and fire as determinants of aboveground biomass," American Journal of Botany, vol. 82, no. 8, pp. 10241030, 1995.

[7] J. M. Paruelo, W. K. Lauenroth, I. C. Burke, and O. E. Sala, "Grassland precipitation-use efficiency varies across a resource gradient," Ecosystems, vol. 2, no. 1, pp. 64-68, 1999.

[8] W. K. Lauenroth, I. C. Burke, and J. M. Paruelo, "Patterns of production and precipitation-use efficiency of winter wheat and native grasslands in the central Great Plains of the United States," Ecosystems, vol. 3, no. 4, pp. 344-351, 2000.

[9] D. U. Hooper and P. M. Vitousek, "The effects of plant composition and diversity on ecosystem processes," Science, vol. 277, no. 5330, pp. 1302-1305, 1997.

[10] D. Tilman, J. Knops, D. Wedin, P. Reich, M. Ritchie, and E. Siemann, "The influence of functional diversity and composition on ecosystem processes," Science, vol. 277, no. 5330, pp. 1300$1302,1997$.

[11] A. Hector, B. Schmid, C. Beierkuhnlein et al., "Plant diversity and productivity experiments in European grasslands," Science, vol. 286, no. 5442, pp. 1123-1127, 1999.

[12] Y. Yang, J. Fang, P. A. Fay, J. E. Bell, and C. Ji, "Rain use efficiency across a precipitation gradient on the Tibetan Plateau,"
Geophysical Research Letters, vol. 37, no. 15, Article ID L15702, 5 pages, 2010.

[13] H. A. Snyman, "Rangeland degradation in a semi-arid South Africa-I: influence on seasonal root distribution, root/shoot ratios and water-use efficiency," Journal of Arid Environments, vol. 60, no. 3, pp. 457-481, 2005.

[14] Y. Z. Gao, M. Giese, S. Lin, B. Sattelmacher, Y. Zhao, and H. Brueck, "Belowground net primary productivity and biomass allocation of a grassland in Inner Mongolia is affected by grazing intensity," Plant and Soil, vol. 307, no. 1-2, pp. 41-50, 2008.

[15] P. Schönbach, H. Wan, M. Gierus et al., "Effects of grazing and precipitation on herbage production, herbage nutritive value and performance of sheep in continental steppe," Grass and Forage Science, vol. 67, no. 4, pp. 535-545, 2012.

[16] I. Noy-Meir, "Desert ecosystems: environment and producers," Annual Review of Ecology and Systematics, vol. 4, no. 1, pp. 2551, 1973.

[17] J. P. Grime, "Evidence for the existence of three primary strategies in plants and its relevance to ecological and evolutionary theory," The American Naturalist, vol. 111, no. 982, pp. 1169-1194, 1977.

[18] H. Brueck, K. Erdle, Y. Z. Gao et al., "Effects of N and water supply on water use-efficiency of a semiarid grassland in Inner Mongolia," Plant and Soil, vol. 328, no. 1-2, pp. 495-505, 2010.

[19] Y. Z. Gao, M. Giese, Q. Gao, H. Brueck, L. X. Sheng, and H. J. Yang, "Community level offset of rain use- and transpiration efficiency for a heavily grazed ecosystem in inner Mongolia grassland," PLoS ONE, vol. 8, no. 9, Article ID e74841, 2013.

[20] Y. Bai, J. Wu, Q. Pan et al., "Positive linear relationship between productivity and diversity: evidence from the Eurasian Steppe," Journal of Applied Ecology, vol. 44, no. 5, pp. 1023-1034, 2007. 

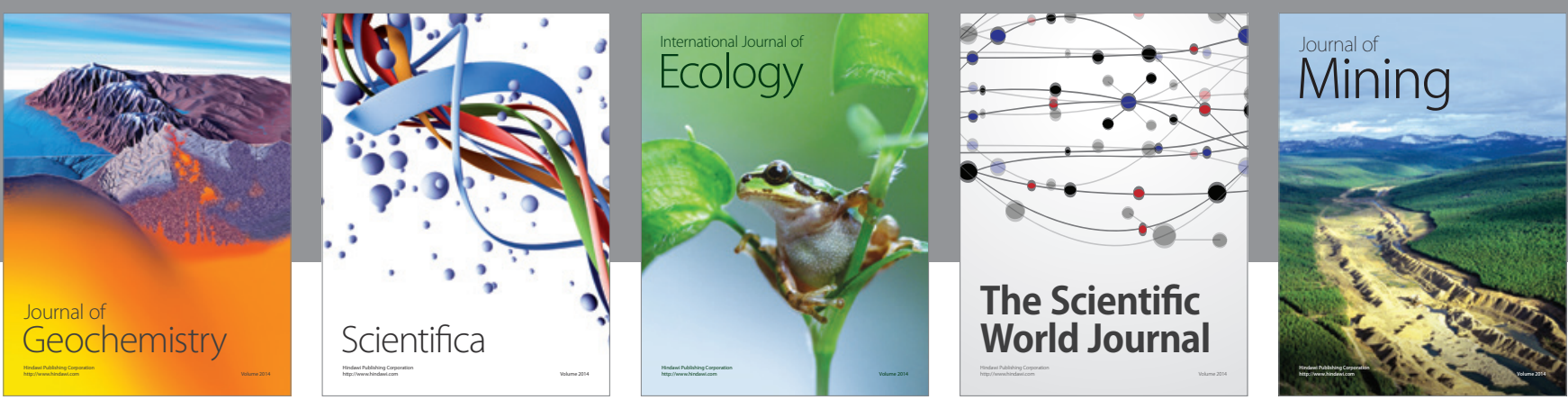

The Scientific World Journal
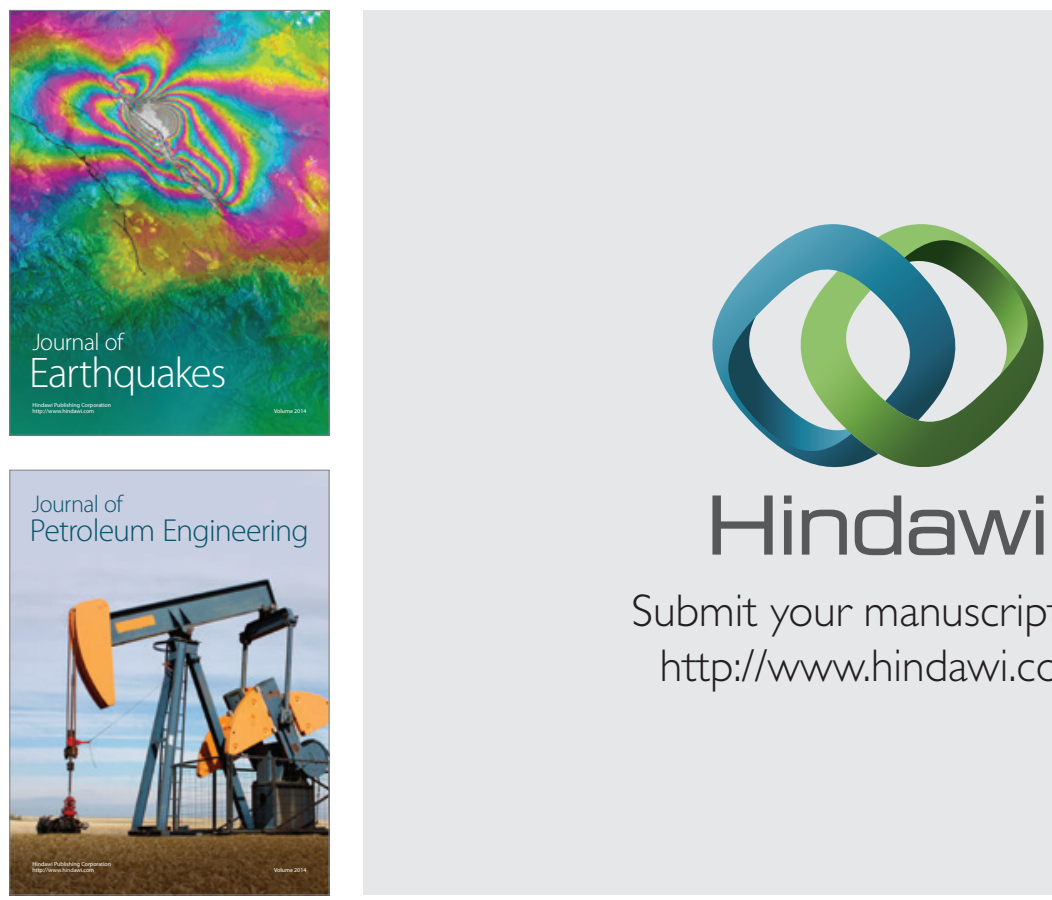

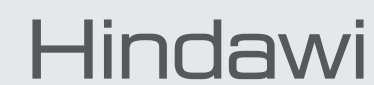

Submit your manuscripts at

http://www.hindawi.com
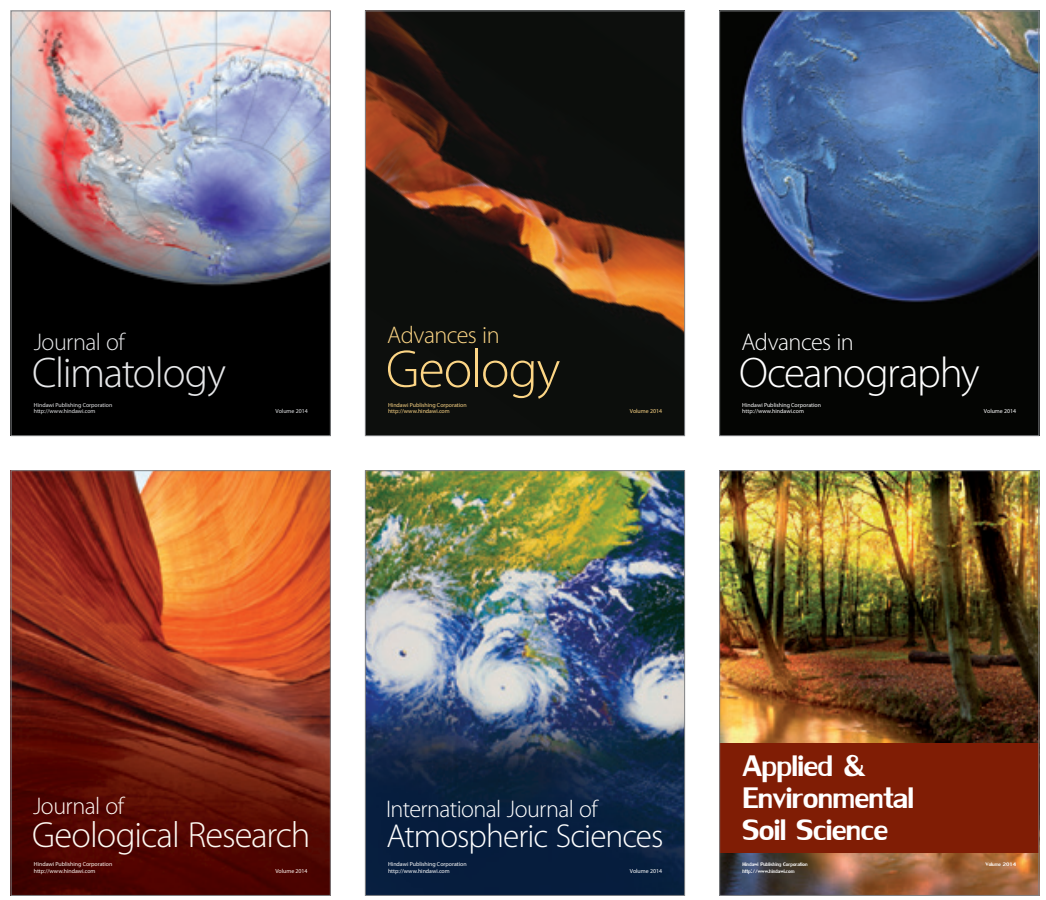
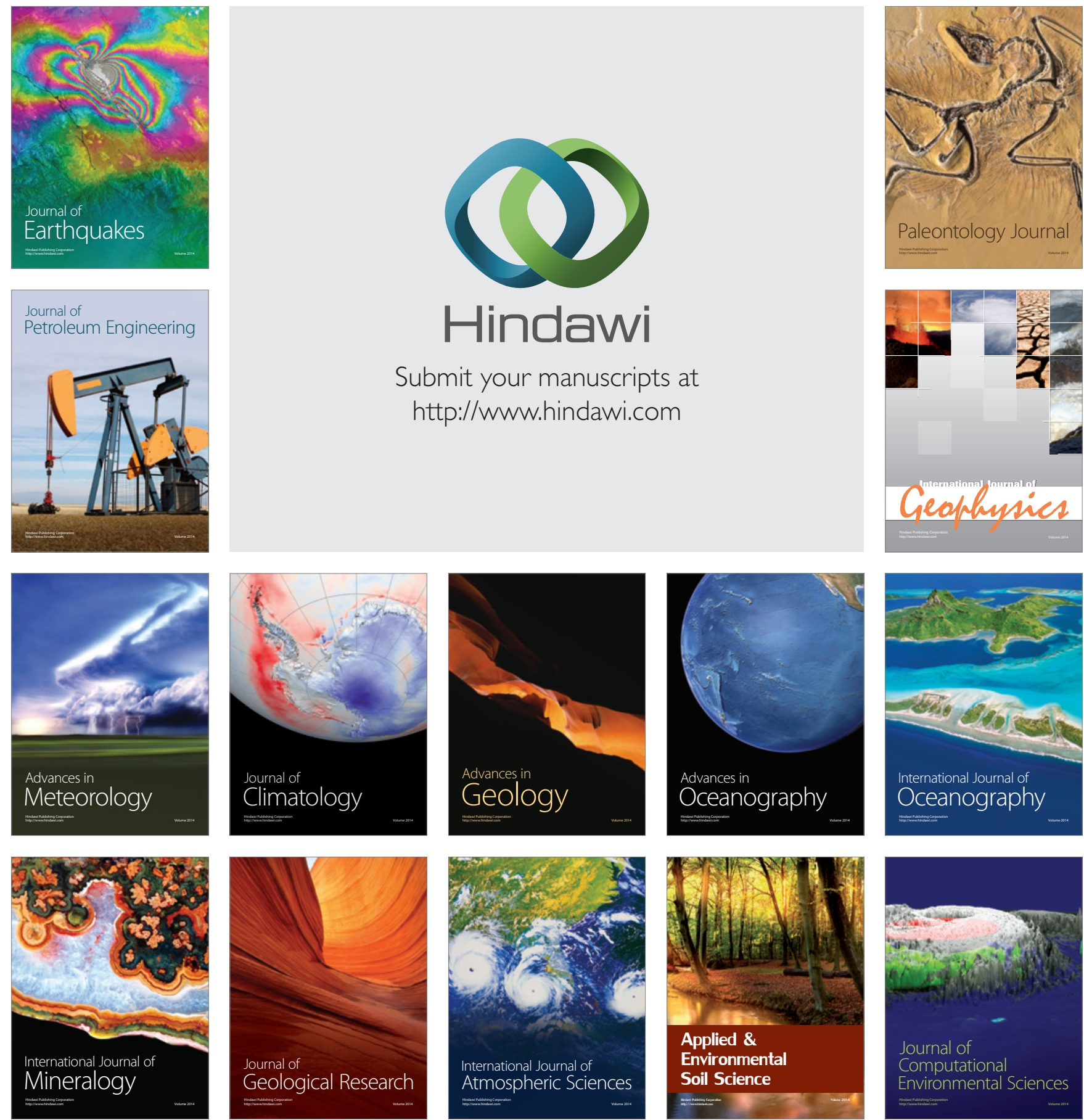